Jurnal Pendidikan Akuntansi Indonesia, Vol. IX. No. 1 - Tahun 2011, Hlm. 74 - 82

\title{
PENILAIAN AFEKTIF DALAM PEMBELAJARAN AKUNTANSI
}

\author{
Oleh \\ Sukanti ${ }^{1}$
}

\begin{abstract}
Abstrak
Terdapat empat karakteristik afektif yang penting dalam pembelajaran yaitu: (1) minat, 2) sikap, 3) konsep diri, dan 4) nilai. Penilaian afektif bertujuan: 1) untuk memperoleh informasi minat peserta didik terhadap mata pelajaran Akuntansi yang selanjutnya digunakan untuk meningkatkannya jika ternyata minat peserta didik rendah, 2) untuk mengetahui sikap peserta didik terhadap mata pelajaran Akuntansi, hasil pengukuran sikap berguna untuk menentukan strategi pembelajaran yang tepat untuk peserta didik, 3) untuk mengetahui kekuatan dan kelemahan diri sendiri, informasi ini dapat digunakan untuk menentukan program yang sebaiknya ditempuh peserta didik untuk menentukan jenjang karir dan 4) untuk mengungkap nilai individu, informasi yang diperoleh ini berupa nilai yang positif dan yang negatif, hal-hal yang positif diperkuat dan yang negatif diperlemah dan akhirnya dihilangkan. Pengukuran afektif dapat dilakukan dengan angket dan pengamatan. Terdapat sepuluh langkah yang harus diikuti dalam pengembangan instrumen afektif yaitu: 1) menentukan spesifikasi instrumen, 2) menulis instrumen, 3) menentukan skala pengukuran, 4) menentukan sistem penskoran, 5) menelaah instrumen, 6) melakukan uji coba, 7) menganalisis instrumen, 8) merakit instrumen, 9) melaksanakan pengukuran, dan 10) menafsirkan hasil pengukuran.
\end{abstract}

\section{Kata kunci: penilaian, afektif}

\section{A. Pendahuluan}

Tujuan pembelajaran meliputi tiga domain yaitu kognitif, afektif dan psikomotor. Aspek kognitif dan psikomotor sudah dilaksanakan oleh para pendidik, sedang aspek afektif belum memperoleh perhatian seperti pada kedua aspek lainnya. Masalah afektif merupakan hal yang penting, namun implementasinya masih kurang, karena merancang pencapaian tujuan pembelajaran afektif tidak semudah seperti pembelajaran kognitif. Ranah afektif harus nampak dalam proses dan hasil belajar yang dicapai peserta didik oleh karena itu harus dinilai hasil-hasilnya. Menurut Popham 1995 dalam Djemari Mardapi (2004) ranah afektif menentukan keberhasilan seseorang. Orang yang tidak memiliki kemampuan afektif yang baik, sulit mencapai keberhasilan studi yang optimal. Hasil belajar kognitif dan psikomotorik akan optimal jika peserta didik mempunyai kemampuan afektif tinggi. Oleh karena itu pendidikan harus diselenggarakan dengan memberikan perhatian yang lebih baik menyangkut ranah afektif ini. Pencapaian kemampuan kognitif dan psikomotor dalam bidang akuntansi tidak akan memberi manfaat bagi masyarakat, apabila tidak diikuti dengan kemampuan afektif. Kemampuan lulusan suatu jenjang pendidikan bisa baik jika digunakan untuk membantu orang lain, namun bisa tidak baik bila kemampuan ini digunakan untuk merugikan pihak lain. Selain itu pengembangan ranah afektif di sekolah akan membawa pengaruh yang sangat positif dalam kehidupan peserta didik selanjutnya, baik di rumah

\footnotetext{
${ }^{1}$ Dosen Jurusan Pendidikan Akuntansi - Universitas Negeri Yogyakarta
} 
maupun di lingkungan luar. Melalui tulisan ini akan dibahas konsep afektif, karakteristik afektif, tujuan penilaian afektif, dan pengembangan instrumen penilaian afektif.

\section{B. Pembahasan \\ 1. Konsep Afektif}

Afektif berhubungan dengan emosi seperti perasaan, nilai, apresiasi, motivasi dan sikap. Terdapat lima kategori utama afektif dari yang paling sederhana sampai kompleks yaitu: penerimaan, tanggapan, penghargaan, pengorganisasian, dan karakterisasi berdasarkan nilai-nilai atau internalisasi nilai.

Receiving (penerimaan) adalah kesediaan untuk menyadari adanya suatu fenomena di lingkungannya. Contohnya mendengarkan orang lain dengan seksama, mendengarkan dan mengingat nama seseorang yang baru dikenalnya. Dalam pengajaran bentuknya berupa mendapatkan perhatian, mempertahankannya, dan mengarahkannya. Tugas pendidik adalah mengarahkan perhatian peserta didik pada fenomena yang menjadi objek pembelajaran afektif. Indikatornya adalah peserta didik: bertanya, memilih, mendeskripsikan, mengikuti, memberikan, mengidentifikasikan, menyebutkan, menunjukkan, menyeleksi, mengulangi, menggunakan.

Responding (tanggapan) adalah memberikan reaksi terhadap fenomena yang ada di lingkungannya. Meliputi persetujuan, kesediaan, dan kepuasan dalam memberikan tanggapan. Pada tingkat ini peserta didik tidak saja memperhatikan fenomena khusus tetapi ia juga bereaksi. Hasil pembelajaran pada ranah ini adalah menekankan pada pemerolehan respon, berkeinginan memberi respon, atau kepuasan dalam memberi respon. Contohnya berpartisipasi di kelas, bertanya tentang konsep, model dan sebagainya agar memperoleh pemahaman, dan menerapkannya. Indikatornya adalah peserta didik: menjawab, membantu, mendiskusikan, menghormati, berbuat, melakukan, membaca, memberikan, menghafal, melaporkan, memilih, menceritakan, menulis. Tingkat yang tinggi pada kategori ini adalah minat, yaitu hal-hal yang menekankan pada pencarian hasil dan kesenangan pada aktivitas khusus. Misal kesenangan membaca buku Akuntansi. Tugas pendidik dalam hal ini adalah berupaya agar peserta didik senang dalam mempelajari Akuntansi.

Valuing (penghargaan) berkaitan dengan harga atau nilai yang diterapkan pada suatu objek, fenomena, atau tingkah laku. Contohnya peka terhadap perbedaan individu dan budaya, menunjukkan kemampuan memecahkan masalah, mempunyai komitmen. Penilaian berdasar pada internalisasi dari serangkaian nilai tertentu yang diekspresikan ke dalam tingkah laku. Indikatornya adalah peserta didik: melengkapi, menggambarkan, membedakan, menerangkan, mengikuti, membentuk, mengundang, menggabung, mengusulkan, membaca, melaporkan, memilih, bekerja, mengambil bagian, mempelajari. Dalam tujuan pembelajaran penilaian ini diklasifikasikan sebagai sikap.

Organization (pengorganisasian) berkaitan dengan memadukan nilai-nilai yang berbeda, menyelesaikan konflik, dan membentuk suatu sistem nilai yang konsisten. Contohnya mengakui adanya kebutuhan keseimbangan antara kebebasan dan tanggungjawab, menyelaraskan antara kebutuhan organisasi, keluarga dan diri sendiri. Indikatornya adalah peserta didik: mengubah, mengatur, menggabungkan, membandingkan, melengkapi, mempertahankan, menerangkan, merumuskan, menggeneralisasikan, mengidentifikasikan, mengintegrasikan, memodifikasikan, mengorganisir, menyiapkan, menghubungkan, mengsintesiskan.

Characterization by a Value or Value Complex (karakterisasi berdasarkan nilai-nilai) berhubungan dengan memiliki sistem nilai yang mengendalikan tingkah-lakunya sehingga menjadi karakteristik gaya-hidupnya. Contohnya menunjukkan kemandiriannya saat bekerja sendiri, kooperatif dalam kegiatan kelompok, objektif dalam memecahkan masalah, 
menghargai orang berdasarkan yang mereka katakan bukan siapa mereka. Indikatornya adalah peserta didik: membedakan menerapkan, mengusulkan, memperagakan, mempengaruhi, mendengarkan, memodifikasikan, mempertunjukkan, menanyakan, memecahkan, menggunakan.

Menurut Sukardi (2008) dalam konteks evaluasi pembelajaran penggunaan kata kerja pada setiap tingkatan ranah afektif, juga dapat digunakan sebagai acuan dalam membuat item-item tes sesuai dengan tingkatan pengetahuan siswa.

\section{Karakteristik Afektif}

Zaenal Arifin. (2009) menjelaskan ada dua hal yang berhubungan dengan penilaian afektif yang harus dinilai. Pertama, kompetensi afektif yang ingin dicapai dalam pembelajaran meliputi tingkatan pemberian respons, apresiasi, penilaian dan internalisasi. Kedua, sikap dan minat peserta didik terhadap mata pelajaran dan proses pembelajaran. Dalam proses pembelajaran terdapat empat tipe karakteristik afektif yang penting yaitu sikap, minat, konsep diri dan nilai.

Sikap adalah suatu predisposisi yang dipelajari untuk merespon secara positif atau negatif terhadap suatu objek, situasi, konsep atau orang. Misalnya objeknya adalah sikap peserta didik terhadap mata pelajaran Akuntansi. Seharusnya sikap peserta didik terhadap mata kuliah Akuntansi lebih positif dibanding sebelum mengikuti proses pembelajaran tersebut. Perubahan sikap ini merupakan indikator keberhasilan pendidik dalam proses pembelajaran. Oleh karena itu pendidik harus membuat rencana pembelajaran termasuk pengalaman pembelajaran yang membuat sikap peserta didik terhadap mata pelajaran menjadi lebih positif. Dengan sikap positif dalam diri peserta didik akan lebih mudah diberi motivasi dan akan lebih mudah menyerap materi pelajaran yang diajarkan. Penilaian sikap pada sekolah menengah kejuruan ada dua yaitu sikap mengikuti pembelajaran sehari-hari dan sikap dalam melaksanakan suatu pekerjaan produktif. Sikap mengikuti pembelajaran bersumber dari catatan harian peserta didik berdasarkan pengamatan guru mata pelajaran, hasil penilaian berdasarkan pertanyaan langsung dan laporan pribadi. Penilaian sikap dalam melaksanakan pekerjaan idealnya dilakukan oleh dua penilai yaitu unsur eksternal (dari industri) dan internal (guru), yang mengacu pada pencapaian kriteria pada setiap kompetensi. Sikap yang dinilai adalah sikap yang dipersyaratkan untuk melakukan suatu pekerjaan.

Minat adalah suatu rasa lebih suka dan rasa ketertarikan pada suatu aktivitas tanpa ada yang menyuruh. Minat berhubungan dengan perhatian, seseorang yang menaruh minat pada mata pelajaran tertentu cenderung untuk memperhatikan mata pelajaran tersebut. Dengan demikian peserta didik yang berminat pada materi Akuntansi akan cenderung memperhatikan mata pelajaran tersebut. Tugas pendidik adalah meningkatkan minat tersebut jika minat peserta didik rendah. Indikator minat antara lain: adanya perasaan suka, ketertarikan, perhatian, kesesuaian, kecenderungan untuk menindaklanjuti.

Nilai merupakan suatu keyakinan tentang perbuatan, tindakan, atau perilaku yang dianggap baik dan yang dianggap jelek. Beberapa ranah afektif yang tergolong penting adalah

a. Kejujuran: peserta didik harus belajar untuk menghargai kejujuran dalam beriteraksi dengan orang lain

b. Integritas: peserta didik harus dapat dipercaya oleh orang lain, mengikat pada kode nilai.

c. Adil: peserta didik harus berpendapat bahwa semua orang memperoleh perlakuan hukum yang sama

d. Kebebasan: peserta didik harus yakin bahwa negara demokratis harus memberi kebebasan secara maksimum kepada semua orang.

Konsep diri adalah evaluasi yang dilakukan individu terhadap kemampuan dan kelemahan yang dimilikinya. Konsep diri ini penting bagi peserta didik untuk menentukan 
jenjang karir mereka yaitu dengan mengetahui kekuatan dan kelemahan diri sendiri maka bisa dipilih alternatif karir yang tepat bagi dirinya. Informasi tentang konsep diri peserta didik ini penting bagi pendidik untuk memotivasi belajar peserta didik dengan tepat.

Menurut Nana Sudjana (2008) hasil belajar ranah afektif dapat menjadi hasil belajar ranah psikomotor jika siswa menunjukkan perilaku atau perbuatan tertentu sesuai dengan makna yang terkandung dalam ranah afektif sehingga akan nampak sebagai berikut:

\begin{tabular}{|l|l|}
\hline Hasil belajar afektif & Hasil belajar psikomotor \\
\hline $\begin{array}{l}\text { Kemauan untuk menerima } \\
\text { pelajaran dari guru }\end{array}$ & $\begin{array}{l}\text { Segera memasuki kelas pada waktu guru datang dan } \\
\text { duduk paling depan dengan mempersiapkan kebutuhan } \\
\text { belajar }\end{array}$ \\
\hline $\begin{array}{l}\text { Perhatian siswa terhadap apa } \\
\text { yang dijelaskan guru }\end{array}$ & Mencatat bahan pelajaran dengan baik dan sistematis \\
\hline $\begin{array}{l}\text { Penghargaan siswa terhadap } \\
\text { guru }\end{array}$ & $\begin{array}{l}\text { Sopan, ramah dan hormat kepada guru pada saat guru } \\
\text { menjelaskan pelajaran }\end{array}$ \\
\hline $\begin{array}{l}\text { Hasrat untuk bertanya kepada } \\
\text { guru }\end{array}$ & $\begin{array}{l}\text { Mengangkat tangan dan bertanya kepada guru } \\
\text { mengenai bahan pelajaran yang belum jelas }\end{array}$ \\
\hline $\begin{array}{l}\text { Kemauan untuk mempelajari } \\
\text { bahan pelajaran lebih lanjut }\end{array}$ & $\begin{array}{l}\text { Keperpustakaan untuk belajar lebih lanjut atau } \\
\text { meminta informasi kepada guru tentang buku yang } \\
\text { harus dipelajari atau segera membentuk kelompok } \\
\text { untuk diskusi }\end{array}$ \\
\hline $\begin{array}{l}\text { Kemauan untuk menerapkan } \\
\text { hasil pelajaran }\end{array}$ & $\begin{array}{l}\text { Melakukan latihan diri dalam memecahkan masalah } \\
\text { berdasarkan konsep bahan yang telah diperolehnya } \\
\text { atau menggunakannya dalam praktik kehidupannya }\end{array}$ \\
\hline $\begin{array}{l}\text { Senang terhadap guru dan mata } \\
\text { pelajaran yang diberikan }\end{array}$ & $\begin{array}{l}\text { Akrab dan mau bergaul, mau berkomunikasi dengan } \\
\text { guru dan bertanya atau meminta saran bagaimana } \\
\text { mempelajari mata pelajaran yang diajarkan }\end{array}$ \\
\hline
\end{tabular}

Pencapaian kemampuan kognitif dan psikomotor dalam bidang akuntansi tidak akan memberi manfaat bagi masyarakat, apabila tidak diikuti dengan kemampuan afektif. Kemampuan lulusan suatu jenjang pendidikan bisa baik jika digunakan untuk membantu orang lain, namun bisa tidak baik bila kemampuan ini digunakan untuk merugikan pihak lain.

\section{Tujuan Penilaian Afektif}

Seorang pendidik sebaiknya mengetahui afektif peserta didik sehingga dapat diketahui status afektif peserta didiknya. Jika afektif tinggi maka perlu mempertahankannya, jika rendah perlu upaya untuk meningkatkannya. Suharsimi Arikunto (2003) menjelaskan pengukuran ranah afektif tidak dapat dilakukan setiap saat (dalam arti pengukuran formal) karena perubahan tingkah laku siswa tidak dapat berubah sewaktu-waktu. Pengubahan sikap seseorang memerlukan waktu yang relatif lama. Demikian juga pengembangan minat dan penghargaan serta nilai-nilainya. Sasaran penilaian afektif adalah perilaku peserta didik bukan pengetahuannya.

Sesuai dengan karakteristik afektif dalam proses pembelajaran adalah minat, sikap, konsep diri dan nilai maka tujuan penilaian afektif adalah:

a. Untuk memperoleh informasi minat peserta didik terhadap mata pelajaran Akuntansi yang selanjutnya digunakan untuk meningkatkan minat peserta didik terhadap mata pelajaran Akuntansi jika ternyata minatnya rendah. 
b. Untuk mengetahui sikap peserta didik terhadap mata pelajaran Akuntansi. Sikap peserta didik terhadap mata pelajaran dapat positif atau negatif. Hasil pengukuran sikap berguna untuk menentukan strategi pembelajaran yang tepat untuk peserta didik.

c. Untuk mengetahui kekuatan dan kelemahan diri sendiri. Peserta didik melakukan evaluasi terhadap potensi yang ada dalam dirinya. Informasi ini dapat digunakan untuk menentukan program yang sebaiknya ditempuh peserta didik untuk menentukan jenjang karir.

d. Untuk mengungkap nilai individu. Informasi yang diperoleh ini berupa nilai yang positif dan yang negatif. Hal-hal yang positif diperkuat dan yang negatif diperlemah dan akhirnya dihilangkan.

\section{Pengembangan Instrumen Penilaian Afektif}

Terdapat sepuluh langkah yang harus diikuti dalam pengembangan instrument penilaian afektif: a) menentukan spesifikasi instrumen, b) menulis instrumen, c) menentukan skala pengukuran, d) menentukan sistem penskoran, e) menelaah instrumen, f) melakukan uji coba, g) menganalisis instrumen, h) merakit instrumen, i) melaksanakan pengukuran, dan j) menafsirkan hasil pengukuran.

\section{a. Menentukan spesifikasi instrumen.}

Spesifikasi instrumen terdiri dari tujuan dan kisi-kisi instrumen.

Instrumen minat bertujuan untuk memperoleh informasi terhadap minat peserta didik terhadap mata pelajaran Akuntansi yang selanjutnya digunakan untuk meningkatkan minat peserta didik tersebut terhadap mata pelajaran Akuntansi. Instrumen sikap bertujuan untuk mengetahui sikap peserta didik terhadap mata pelajaran Akuntansi. Sikap peserta didik terhadap mata pelajaran dapat positif atau negatif. Hasil pengukuran sikap berguna untuk menentukan strategi pembelajaran yang tepat untuk peserta didik. Instrumen konsep diri bertujuan untuk mengetahui kekuatan dan kelemahan diri sendiri. Peserta didik melakukan evaluasi terhadap potensi yang ada dalam dirinya. Informasi ini dapat digunakan untuk menentukan program yang sebaiknya ditempuh peserta didik untuk menentukan jenjang karir. Instrumen nilai bertujuan untuk mengungkap nilai individu. Informasi yang diperoleh ini berupa nilai yang positif dan yang negatif. Hal-hal yang positif diperkuat dan yang negatif diperlemah dan akhirnya dihilangkan.

Kisi-kisi merupakan tabel yang berisi spesifikasi instrumen yang akan ditulis. Kisikisi pada dasarnya berisi tentang definisi konseptual yang ingin diukur, kemudian ditentukan definisi operasional dan selanjutnya diuraikan menjadi sejumlah indikator. Indikator ini merupakan acuan untuk menulis instrumen. Pertanyaan yang ditulis ini berdasar indikator. Tiap indikator dapat ditulis dua atau lebih pertanyaan.

\section{b. Menulis instrumen.}

Terdapat empat aspek penting dari ranah afektif dalam proses pembelajaran yaitu sikap, minat, konsep diri dan nilai.

Cara yang mudah untuk mengetahui sikap peserta didik terhadap mata pelajaran Akuntansi adalah dengan angket. Pertanyaan tentang sikap meminta peserta didik menunjukkan perasaan positif atau negatif terhadap mata pelajaran Akuntansi. Kata-kata yang dapat digunakan pada pertanyaan sikap menyatakan pada arah perasaan seseorang misalnya: menerima-menolak, menyenangi-tidak menyenangi, baik-buruk, diinginkan-tidak diinginkan. Indikator sikap terhadap mata pelajaran akuntansi misalnya: membaca buku Akuntansi, belajar Akuntansi, interaksi dengan dosen Akuntansi, mengerjakan tugas Akuntansi, diskusi tentang akuntansi, memiliki buku Akuntansi. 
Instrumen penilaian minat bertujuan untuk memperoleh informasi tentang minat peserta didik terhadap suatu mata pelajaran yang selanjutnya dapat digunakan untuk meningkatkan minat peserta didik pada mata pelajaran tersebut. Minat adalah keingintahuan seseorang tentang keadaan suatu objek. Indikator minat, misalnya minat terhadap mata pelajaran Akuntansi: mengetahui kemanfaatan belajar Akuntansi, usaha memahami Akuntansi, membaca buku Akuntansi, bertanya di kelas, bertanya pada teman, bertanya pada orang lain, mengerjakan soal Akuntansi.

Instrumen konsep diri bertujuan untuk mengetahui kekuatan dan kelemahan diri sendiri. Informasi kekuatan dan kelemahan diri sendiri digunakan untuk menentukan program yang sebaiknya ditempuh oleh peserta didik. Konsep diri adalah pernyataan tentang kemampuan diri sendiri yang menyangkut mata pelajaran. Indikator konsep diri tentang akuntansi misalnya perasaan sulit mudahnya mata pelajaran Akuntansi, keunggulan dan kelemahan dalam mempelajari Akuntansi.

Nilai seseorang pada dasarnya terungkap melalui bagaimana ia berbuat atau keinginan berbuat. Nilai adalah keyakinan seseorang tentang keadaan suatu objek atau kegiatan, misal keyakinan akan kemampuan peserta didik, keyakinan tentang kinerja pendidik. Instrumen nilai bertujuan untuk mengungkap nilai dan keyakinan individu. Indikator nilai dalam bidang akuntansi misalnya keyakinan tentang prestasi belajar Akuntansi, keberhasilan belajar peserta didik, keyakinan harapan orang tua, keyakinan atas dukungan masyarakat, keyakinan atas sekolah bahwa sekolah dapat mengubah nasip mereka.

Selain menggunakan angket, informasi tentang afektif dapat digali dengan pengamatan. Pengamatan ranah afektif dapat dilakukan di tempat proses pembelajaran. Untuk mengetahui keadaan ranah afektif peserta didik, pendidik harus menyiapkan diri untuk mencatat setiap tindakan yang muncul dari peserta didik yang berkaitan dengan indikator ranah afektif peserta didik tersebut. Oleh karena itu perlu ditentukan indikator substansi yang akan diukur.

c. Menentukan skala instrumen.

Secara garis besar skala instrumen yang sering digunakan dalam penilaian adalah skala Thurstone, skala Likert, dan skala Beda Semantik. Skala Thurstone terdiri dari 7 kategori yang paling banyak bernilai 7 dan yang paling kecil bernilai 1 .

Contoh skala Thurstone, Minat terhadap mata pelajaran Akuntansi

Saya senang belajar Akuntansi

$$
\begin{array}{lllllll}
7 & 6 & 5 & 4 & 3 & 2 & 1
\end{array}
$$

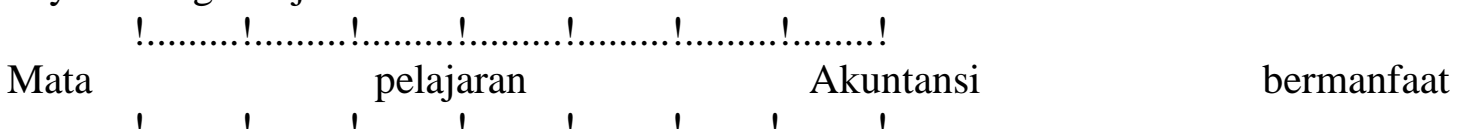

Saya berusaha hadir tiap ada mata

pelajaran Akuntansi

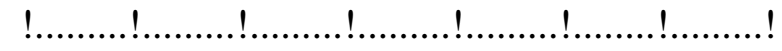

Saya berusaha memiliki buku

Akuntansi

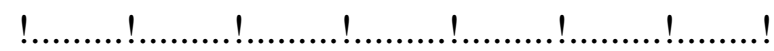

Pelajaran Akuntansi membosankan

!...............................................................!

Skala Likert, Sikap terhadap mata pelajaran Akuntansi

$\begin{array}{llll}\begin{array}{l}\text { Pelajaran Akuntansi bermanfaat } \\ \text { STS }\end{array} & \text { SS } & \text { S } & \text { TS } \\ \begin{array}{l}\text { Pelajaran Akuntansi sulit } \\ \quad \text { STS }\end{array} & \text { SS } & \text { S } & \text { TS }\end{array}$




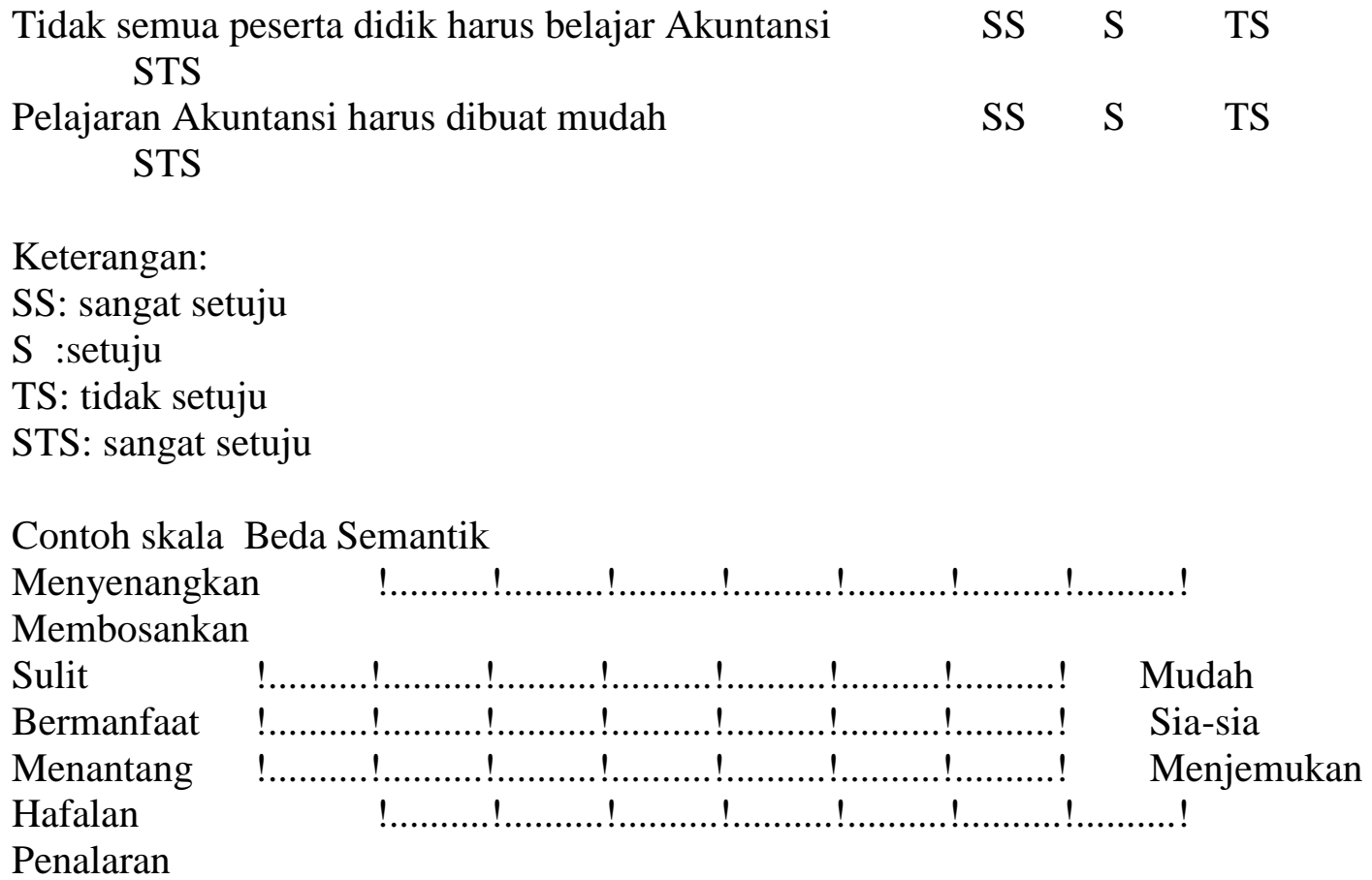

Panjang instrumen berhubungan dengan masalah kebosanan, yaitu tingkat kejemuan dalam mengisi instrumen. Lama pengisian instrumen sebaiknya tidak lebih dari 30 menit d. Menentukan sistem penskoran.

Sistem perskoran yang digunakan tergantung pada skala pengukuran yang digunakan. Apabila menggunakan skala Thurstone maka skor tertinggi untuk tiap butir 7 dan skor terendah 1. Demikian pula untuk instrumen dengan skala beda semantik tertinggi 7 dan terendah 1. Untuk skala Likert skor tertinggi 4 dan skor terendah 1. Dalam pengukuran sering terjadi kecenderungan responden memilih jawaban pada kategori 3 untuk skala Likert, untuk mengatasi hal ini skala Likert hanya menggunakan 4 pilihan agar jelas sikap atau minat peserta didik yaitu sangat setuju:4, setuju: 3, tidak setuju: 2, dan sangat tidak setuju :1.

e. Menelaah instrumen

Kegiatan menelaah instrumen adalah meneliti tentang: 1) apakah butir pertanyaan atau pernyataan sesuai dengan indikator, 2) apakah bahasa yang digunakan sudah komunikatif dan menggunakan tata bahasa yang benar, 3) apakah butir pertanyaan atau pernyataan tidak bias, 4) apakah format instrumen menarik untuk dibaca, 5) apakah jumlah butir sudah tepat sehingga tidak menjemukan menjawabnya. Telaah dilakukan oleh pakar dalam bidang yang diukur. Telaah bisa juga dilakukan oleh teman sejawat bila yang diinginkan adalah masukan tentang bahasa dan format instrumen. Bahasa yang digunakan sesuai dengan tingkat pendidikan peserta didik. Hasil telaah ini selanjutnya digunakan untuk memperbaiki instrumen.

\section{f. Melakukan uji coba.}

Instrumen yang telah ditelaah kemudian diperbaiki untuk uji coba. Uji coba bertujuan untuk mengetahui karakteristik instrumen. Karakteristik yang penting adalah keandalannya. Selanjutnya dihitung keandalannya dengan formula Cronbach alpha, bila besarnya indeks sama atau lebih besar dari 0,7 maka instrumen itu tergolong baik.

g. Menganalisis instrumen. 
Berdasarkan hasil uji coba dapat diketahui kualitas instrumen tersebut. Dengan demikian dapat dilakukan perbaikan-perbaikan jika masih ada pertanyaan atau pernyataan yang belum sesuai dengan yang diharapkan. Ada kemungkinan pertanyaan sudah baik sehingga tidak perlu diperbaiki, dan ada beberapa butir yang mungkin perlu diperbaiki dan mungkin ada sebagian yang harus dibuang karena tidak baik.

h. Merakit instrumen.

Setelah instrumen dianalisis dan diperbaiki, langkah berikutnya adalah merakit instrumen menjadi satu keseluruhan.

i. Melaksanakan pengukuran.

Instrumen yang telah disusun diberikan kepada peserta didik untuk diisi. Dalam pelaksanaan ini perlu dipantau agar instrumen itu betul-betul diisi oleh peserta didik yang bersangkutan dengan jujur dan sesuai dengan ketentuan. Pelaksanaan pengukuran ini perlu dilaksanakan secara hati-hati agar tujuan pengukuran dapat tercapai.

\section{j. Menafsirkan hasil pengukuran}

Setelah dilakukan pengukuran, selanjutnya dilakukan analisis untuk tingkat individu dan tingkat kelas dan ditafsirkan hasilnya untuk mengetahui misalnya minat individu dan minat kelas terhadap mata pelajaran Akuntansi. Untuk menafsirkan hasil pengukuran diperlukan suatu kriteria. Kriteria yang digunakan tergantung dari skala dan jumlah butir yang digunakan. Misalkan digunakan skala Likert dengan 4 pilihan untuk mengukur sikap peserta didik yaitu: sangat setuju: 4, setuju:3, tidak setuju:2, dan sangat tidak setuju: 1. Instrumen yang telah diisi dicari skor keseluruhannya sehingga tiap peserta didik memiliki skor.

Misal untuk mengungkap data sikap peserta didik terhadap mata pelajaran Akuntansi dengan 6 pertanyaan. Penilaian dapat dilakukan dengan kriteria sebagai berikut:

$\begin{array}{lc}\text { Skor minimal } & : 6 \times 1=6 \\ \text { Skor maksimal } & : 6 \times 4=24 \\ & 24-6 \\ \text { Rentang nilai } & :------=4,5 \\ & 4\end{array}$

Kategorisasi sikap sebagai berikut:

Sangat positif : 20 - 24
Positif : : $15-19$
Negatif $: 10-14$
Sangat negatif : 5 - 9

Untuk kategorisasi kelas dapat digunakan kriteria berikut ini. Misal satu kelas terdiri dari 40 peserta didik maka:

$\begin{array}{lc}\text { Skor minimum } & : 40 \times 6 \times 1=240 \\ \text { Skor maksimum } & : 40 \times 6 \times 4=960 \\ & 960-240 \\ \text { Rentang nilai }= & ----------=180\end{array}$

Sangat positif : $780-960$

Positif : :600-779

Negatif : : $420-599$

Sangat negatif : 240 - 419 
Dari kategorisasi ini dapat diketahui kecenderungan sikap peserta didik terhadap mata pelajaran Akuntansi

\section{Penutup}

Afektif merupakan perasaan dan emosi. Ada empat karakteristik afektif yang penting dalam pembelajaran adalah: (1) minat, 2) sikap, 3) konsep diri, dan 4) nilai. Instrumen afektif bertujuan: 1) untuk memperoleh informasi terhadap minat peserta didik terhadap pelajaran Akuntansi yang selanjutnya digunakan untuk meningkatkan minat peserta didik terhadap mata pelajaran Akuntansi jika minatnya rendah, 2) untuk mengetahui sikap peserta didik terhadap mata pelajaran Akuntansi, hasil pengukuran sikap berguna untuk menentukan strategi pembelajaran yang tepat untuk peserta didik, 3) untuk mengetahui kekuatan dan kelemahan diri sendiri, informasi ini dapat digunakan untuk menentukan program yang sebaiknya ditempuh peserta didik untuk menentukan jenjang karir dan 4) untuk mengungkap nilai individu, informasi yang diperoleh ini berupa nilai yang positif dan yang negatif, hal-hal yang positif diperkuat dan yang negatif diperlemah dan akhirnya dihilangkan.

Pengukuran afektif dapat dilakukan dengan angket dan pengamatan. Terdapat sepuluh langkah yang harus diikuti dalam pengembangan instrumen afektif: 1) menentukan spesifikasi instrumen, 2) menulis instrumen, 3) menentukan skala pengukuran, 4) menentukan sistem penskoran, 5) menelaah instrumen, 6) melakukan uji coba, 7) menganalisis instrumen, 8) merakit instrumen, 9) melaksanakan pengukuran, dan 10) menafsirkan hasil pengukuran.

\section{Daftar Pustaka}

Anas Sudijono.2005. Pengantar Evaluasi Pendidikan. Jakarta: PT RajaGrafindo Persada.

Djemari Mardapi. 2004. Penyusunan Tes Hasil Belajar. Yogyakarta: Program Pascasarjana Universitas Negeri Yogyakarta.

Nana Sudjana. 2008. Penilaian Hasil Proses Belajar Mengajar. Bandung: Remaja Rosdakarya

Pusat Kurikulum Model Penilaian Kelas Kurikulum Berbasis Kompetensi. Jakarta: Balitbang Depdiknas.

Suharsimi Arikunto (2003). Dasar-Dasar Evaluasi Pendidikan. Jakarta: Bumi Aksara.

Sukardi (2008). Evaluasi Pendidikan Prinsip \& Operasionalnya. Jakarta: Bumi Aksara.

Zaenal Arifin. 2009. Evaluasi Pembelajaran Prinsip Teknik. Prosedur. Bandung: Remaja Rosdakarya. 